\title{
Democratic Redistribution and Rule of the Majority
}

\author{
Giacomo Corneo \\ Frank Neher
}

CESIFO WORKING PAPER NO. 5112

CATEgory 1: Public FinANCE

DECEMBER 2014

\author{
An electronic version of the paper may be downloaded \\ - from the SSRN website: \\ - from the RePEc website: \\ - from the CESifo website: \\ WwW.SSRN.com \\ Www.RePEc.org \\ www.CESifo-group.org/wp
}

\section{CESifo}




\title{
Democratic Redistribution and Rule of the Majority
}

\begin{abstract}
Does redistribution in democracies cater to the will of the majority? We propose a direct empirical strategy based on survey data that needs not assume that voters are guided by pecuniary motives alone. We find that most democracies implement the median voter's preferred amount of redistribution and the probability to serve the median voter increases with the quality of democracy. However, there is a non-negligible share of democracies that implement a minority-backed amount of redistribution. Political absenteeism of the poor cannot explain such outcomes. Rather, they can be explained by the electoral bundling of redistribution with values and rights issues.
\end{abstract}

JEL-Code: D300, D700, H100, P160.

Keywords: income redistribution, democracy, median-voter theorem, inequality.

Giacomo Corneo

Free University of Berlin

Berlin / Germany

giacomo.corneo@fu-berlin.de
Frank Neher

Free University of Berlin

Berlin / Germany

frank.neher@fu-berlin.de

November 2014 


\section{Introduction}

Redistribution is one of the central domains upon which democratic polities have the power to make far-reaching decisions. But does redistribution in democracies occur in "a democratic way”, i.e. does it cater to the will of the majority of citizens? And if not, what are the driving forces that determine actual redistributive politics in democracies?

Economists often employ the median-voter theorem to describe how the preferences of the electorate translate into policy outcomes. ${ }^{1}$ The amount of redistribution preferred by the median voter obtains in equilibrium because at that level one half of the electorate prefers redistribution to be carried further and one half of the electorate prefers to reduce it. Thus, the median-voter theorem epitomizes the view of democracy as "rule of the majority".

We refer to the presumption that democracies implement the distributional preferences of the median voter as to the median-voter view on redistribution. Despite its prominence in modelling and its intuitive appeal, this view is far from being generally accepted. This dispute is not merely of academic interest: assessing the validity of the median-voter view informs political judgments about the actual working of democracy. A recent example where this issue came to the fore is the controversy about the reasons why democracy has not slowed rising income inequality during the last three decades, both in the U.S. and elsewhere (see e.g. Bartels, 2008, Bonica et al., 2013, and references therein). A popular statement in this debate is that actual redistributive policies substantially depart from those preferred by the majority of citizens, i.e. the median-voter view on redistribution is misleading.

While it is not difficult to criticize the assumptions upon which the median-voter theory is based, its empirical falsification has proven to be a daunting task. The seminal contributions by Romer (1975), Roberts (1977) and Meltzer and Richard (1981) identified the median voter with the individual with the median productivity in the population. Subsequent empirical analyses have therefore investigated the link between the level of redistribution and the distance between the median and the average wage rate (viz. pre-tax income) or the Gini coefficient of the distribution of market incomes. Investigations along those lines have usually produced either mixed or negative results (e.g. Perotti, 1996; Milanovic, 2000; Georgiadis and Manning, 2012; Scervini, 2012).

However, the observation that actual redistribution does not seem to cater to the preferences of the individual with median productivity is no refutation of the median-voter view. The coincidence of the median voter with the individual with median productivity is an

\footnotetext{
${ }^{1}$ Examples include Alesina and Angeletos (2005), Alesina and Rodrik (1994), Bénabou and Ok (2001), Bénabou and Tirole (2006), Lindbeck et al. (1999), Persson and Tabellini (1994) and Piketty (1995).
} 
artefact of the basic model of redistributive taxation. It is not a general property of the median-voter view on redistribution. In a more general version of that model, citizens' preferences for redistribution can hinge upon a variety of non-pecuniary factors. Unless pecuniary and non-pecuniary motives are perfectly correlated, the individual that is the median in the distribution of skills or pre-tax incomes does not need to be the median in the distribution of preferences for redistribution. Therefore, empirical analyses that relate pre-fisc income inequality to redistribution cannot answer the question whether democracies redistribute according to the will of the majority. ${ }^{2}$

Empirical investigations of individual preferences for redistribution suggest that the above observation is germane to a fair appraisal of the median-voter view. A common finding from both survey and experimental evidence is that people often express a demand for redistribution that apparently contradicts their pecuniary self-interest. Correspondingly, several papers including Alesina and Giuliano (2010), Corneo and Grüner (2002), Dahlberg et al. (2012), Fong (2001), Höchtl et al. (2012), Klor and Shayo (2010), Luttmer, (2001), Luttmer and Singhal (2011), Shayo (2009) and Tyran and Sausgruber (2006) have found that preferences for redistribution are significantly affected by non-pecuniary motives. Chief among them are concerns for justice, identity, and social status. Furthermore, individuals' attitudes towards redistribution have been found to depend on their beliefs about the costs inflicted by redistribution to the overall economy and on their perceptions of inequality and income mobility (Alesina and La Ferrara, 2005; Bernasconi, 2006; Engelhardt and Wagener, 2014; Osberg and Smeeding, 2006; Ravallion and Lokshin, 2000). Those concerns and beliefs vastly differ across individuals and display no robust relationship to their wage rates or pretax incomes.

In the current paper, we try to assess the empirical validity of the median-voter view on redistribution without imposing any a priori restriction on voters' preferences. We follow a novel empirical strategy that sidesteps the problem of identifying the median voter on the basis of its skills, preferences, and beliefs. Our strategy consists of directly eliciting the median voter's preference for redistribution from surveys. The dataset we use is representative of the adult population in a large number of countries - both democracies and non-democracies - in a number of years. That dataset allows us to recover for each country and year the entire distribution of desired deviations from the amount of redistribution in the status quo. We use this information to ascertain whether the distributional preferences of the

\footnotetext{
${ }^{2}$ Corneo and Grüner (2000) present a model in which individuals care about others' beliefs about own relative income and show that an increase of pre-fisc inequality can decrease the amount of redistribution even if the median voter coincides with the individual with median pre-fisc income.
} 
median voters are implemented and, if not, how they differ from actual redistribution. By comparing democracies with non-democracies, we then assess the distinctive ability of democracy to implement the will of the majority.

Our findings give some qualified support to the median-voter view on redistribution. We find that, in democracies, variations in the amount of redistribution tend to mirror variations in the preferences of the median voters in the various countries and years. Furthermore, democracies are different from non-democracies in the extent to which redistribution caters to the preferences of the median voter: the higher the quality of democracy, as measured by standard indexes, the higher the probability that the government implements the level of redistribution demanded by the median voter. ${ }^{3}$ Differently from the bulk of the previous literature, our findings suggest that, as a first approximation, redistribution in democracies does conform to the will of the majority. Differently from what is assumed in the basic model of redistributive taxation, we find that median voters and median-income receivers usually constitute quite different sets of people with little overlap.

While democracies often do a good job in serving the median voter, the alignment of redistributive policies to the will of the majority is far from perfect. In about forty percent of the democratic countries in our sample there exists a strict majority of citizens that would prefer a different amount of redistribution. There are both cases where the majority prefers more redistribution than in the status quo and cases where it prefers less redistribution. In the second part of the paper we further scrutinize this finding by putting to test two prominent theories of minority-supported redistributions.

The first one is the asymmetric-participation theory (e.g. Bénabou, 2000). It purports that some groups of the population do not participate in elections and that citizens exert unequal influence on political outcomes. This can generate a gap between the hypothetical and the actual median voter, leading to a level of redistribution that is not the one preferred by the majority of the population.

The second theory we resort to is the policy-bundle theory (e.g. Roemer, 2001). It grounds on the observation that electoral competitions involve several dimensions. Voters do not express themselves on redistribution alone, but on a bundle of policies that include the level of redistribution. If non-redistributive issues - like race and religion - are salient, parties may target redistributive policies to the groups that take a moderate stand in the nonredistributive issues, i.e. to the median voters in those dimensions. Those groups, however,

\footnotetext{
${ }^{3}$ This does not imply that democracy increases redistribution - an issue that has been studied by a voluminous empirical literature and recently summarized and extended by Acemoglu et al. (2013). They put forward that democracy has a robust effect on tax revenues as a fraction of GDP, but ambiguous effects on income inequality.
} 
may have redistributive tastes that substantially differ from those of the median voter on the redistributive issue.

In accordance with the asymmetric-participation theory, we find that political participation significantly correlates with education and income. However, we find that the effect of this asymmetry on redistributive politics is weak, i.e. it does not significantly contribute to explain why the level of redistribution may differ from the one preferred by the majority of citizens.

The policy-bundle theory proves to be very helpful to interpret the data. Consistent with it, we find that redistributive policies tend to adjust to the preferences of the voters who hold median views on values issues. The distance between those preferences and the preferences of the median voter in the redistribution dimension significantly contributes to explain why in democracies the level of redistribution sometimes differs from the one that is desired by the majority of the population.

\section{Descriptive Evidence}

We exploit information on individual preferences for redistribution from the World Values Survey and the European Values Study, together referred to as WVS (WVS 2006, WVS 2012, EVS 2011) ${ }^{4}$. The survey waves were carried out around 1981, 1990, 1995, 2000, 2008 and 2012. In each wave, the survey project was conducted over a period of about three years and for each country the year when the survey was actually fielded is known. As we are interested in the perspective of voters, we restrict the sample to respondents who are eighteen or older at the time the survey was conducted.

For the waves 2 to 7, the WVS-dataset contains an indicator of individuals' attitudes towards redistribution. In the section on economic policy, the respondents' views on the following issue are surveyed: "Incomes should be made more equal” vs. "We need larger income differences as incentives”. Respondents have to select an answer from a scale from 1 to 10 where 1 means that they completely agree with the first statement (they demand more redistribution) and 10 means that they completely agree with the second statement (they demand less redistribution). ${ }^{5}$

The survey question on redistribution was answered by some 385,000 individuals; the frequency distribution of their answers is reported in Table A1 of the Appendix.

\footnotetext{
${ }^{4}$ For details see http://www.worldvaluessurvey.org and http://www.europeanvaluesstudy.eu.

${ }^{5}$ Klor and Shayo (2010), Murthi and Tiongson (2009) and Shayo (2009) employ the same survey question to investigate the drivers of preferences for redistribution.
} 
The use of comparatives in the wording of the question (more equal, larger differences) allows one to infer that respondents use the income distribution in their respective contexts as a benchmark. Accordingly, that question can be used to recover satisfaction with the amount of redistribution actually achieved by the government in a given country and year. More precisely, individuals who view their distributive preferences implemented in the status quo are expected to answer by placing themselves in the middle of the scale, i.e. selecting either point 5 or 6 in the scale. Conversely, individuals who are very dissatisfied with the distributive policy in their country are expected to place themselves at the extremes of the scale.

Respondents' choices on the 1-10 scale may be viewed as the peaks of some underlying well-behaved reduced-form utility functions that describe how expected utilities vary with the amount of redistribution. A choice in the middle of the scale tells us that the respondent's peak lies at the amount of redistribution that exists in the status quo. A choice at the far right of the scale indicates that utility is perceived to reach its maximum at a much lower amount of governmental redistribution. A choice at the far left indicates that distributive preferences peak at a much higher level of redistribution than in the status quo. ${ }^{6}$

This way of eliciting attitudes towards redistribution invites one to define a variable that captures respondents' misalignment with governmental redistribution. We denote that variable by $\Delta$ and set it equal to $|\delta|$, where $\delta$ is the smallest difference between the chosen category and the median categories 5 and 6 . Thus, $\Delta$ equals 0 if the respondent chose 5 or 6 , it equals 1 if the respondent chose 4 or 7, 2 for response category 3 or 8 , etc. Denoting the individual response by $r_{i} \in\{1, \ldots, 10\}$, the preferred change in redistributive policy advocated by individual $i$ is measured by

$$
\delta_{i}=\left\{\begin{array}{l}
r_{i}-5 \text { if } r_{i}<6 \\
r_{i}-6 \text { if } r_{i}>5
\end{array}\right.
$$

In our initial sample there are 313 country/year observations from 110 countries and not all of them are democracies. In order to identify democracies we rely on two indicators from, respectively, the Polity IV dataset (Marshall et al. 2013) and the Freedom House index, see Appendix B1 for details. In some cases those indicators disagree. We thus concentrate on the

\footnotetext{
${ }^{6}$ Notice that our interpretation does not require respondents' perceptions of inequality to be correct in an objective sense. The same applies to respondents' perceptions of the government's ability to affect inequality by means of redistributive policies.
} 
270 country/wave observations for which both indicators are available and classify a country/year observation as a democracy if and only if that observation is classified as a democracy according to both indicators. We call the resulting dummy variable free_polity; it equals 1 in case of a democracy and 0 otherwise. Accordingly, the sample we concentrate on has 163 country/year observations pertaining to democracies and 107 pertaining to nondemocracies. Virtually the entire variation in that variable is cross-country as most countries keep their status as democracy or non-democracy unchanged in all waves. ${ }^{7}$

Table 1 shows separately for democracies and non-democracies the distribution of individual disagreement with status-quo redistribution $\left(\Delta_{i}\right)$. The share of people who are content with the amount of redistribution in their country $\left(\Delta_{i}=0\right)$ is not appreciably higher in democracies than in non-democracies. This is however immaterial to the median-voter view. According to it, the distinctive feature of democracy is not to implement the ideal policy of a majority of people. Rather, it is to implement such a policy that one half of the citizenry would like to have more redistribution and the other half would like to have less of it.

Table 1. Absolute and relative frequency distribution of $\Delta_{i}$

\begin{tabular}{|c|c|c|c|}
\hline & \multicolumn{2}{|c|}{ free_polity } & Total \\
\hline$\Delta_{i}$ & 1 & 0 & \\
\hline \multirow[t]{2}{*}{0} & 48,848 & 33,663 & 82,511 \\
\hline & 22.36 & 20.16 & 21.41 \\
\hline \multirow[t]{2}{*}{1} & 41,254 & 25,279 & 66,533 \\
\hline & 18.89 & 15.14 & 17.26 \\
\hline \multirow[t]{2}{*}{2} & 47,485 & 31,876 & 79,361 \\
\hline & 21.74 & 19.09 & 20.59 \\
\hline \multirow[t]{2}{*}{3} & 26,283 & 22,828 & 49,111 \\
\hline & 12.03 & 13.67 & 12.74 \\
\hline \multirow[t]{2}{*}{4} & 54,567 & 53,324 & 107,891 \\
\hline & 24.98 & 31.94 & 27.99 \\
\hline \multirow[t]{2}{*}{ Total } & 218,437 & 166,970 & 385,407 \\
\hline & 100.00 & 100.00 & 100.00 \\
\hline
\end{tabular}

We are now in a position to examine the extent to which the median voter - in dictatorships the hypothetical median voter - is served in terms of actual redistributive policy. For every country/year we compute the frequency distribution of the original $r_{i}$ variable. This allows us to recover the preferred policy of the median voter, i.e. the voter such that her peak is the median in the distribution of all peaks. Accordingly, for each country/year we compute the

\footnotetext{
${ }^{7}$ Descriptive statistics and analyses pertaining to each original indicator of democracy separately are presented in Appendix C and Appendix D.
} 
value of the $r_{i}$ variable when its cumulative distribution reaches $50 \%$ and then transform that value into a value of $\delta$, following its definition as given above. This $\delta$ at the $50-\%$ level of the cumulative distribution is denoted by $\delta_{m}$. It portrays for any given country/year the misalignment of the preferences of the median voter from the distributive policy implemented by the government. ${ }^{8}$ We refer to $\Delta_{m}=\left|\delta_{m}\right|$ as to the median voter's disagreement with the government. These measures are depicted in Table 2 separately for democratic and nondemocratic countries. $^{9}$

Table 2. $\delta_{m}$ and $\Delta_{m}$ for democracies and non-democracies.

\begin{tabular}{c|ccc|cccc}
\hline \multicolumn{3}{|c}{ free_polity } & \multicolumn{5}{c}{ free_polity } \\
\hline$\delta_{m}$ & 1 & 0 & Total & $\Delta_{m}$ & 1 & 0 & Total \\
& & & & & & & \\
-3 & 1 & 1 & 2 & & & & \\
-2 & 13 & 4 & 17 & & & & \\
-1 & 12 & 6 & 18 & & & & \\
0 & 94 & 42 & 136 & 0 & 94 & 42 & 136 \\
1 & 30 & 29 & 59 & 1 & 42 & 35 & 77 \\
2 & 11 & 17 & 28 & 2 & 24 & 21 & 45 \\
3 & 2 & 7 & 9 & 3 & 3 & 8 & 11 \\
4 & 0 & 1 & 1 & 4 & 0 & 1 & 1 \\
& & & & & & & \\
Total & 163 & 107 & 270 & Total & 163 & 107 & 270 \\
\hline
\end{tabular}

Table 2 reveals two interesting facts. First, almost sixty percent of democracies implement the distributive preferences of the median voter $\left(\Delta_{m}=0\right)$. In other words, in the majority of cases, democracies turn out to implement an amount of redistribution that would be endorsed by a majority of the population against any possible alternative amount. This is a remarkable achievement in view of the unavoidable delays of governmental action in response to all sorts of shocks that may change the amount of redistribution desired by the citizenry.

Second, Table 2 reveals a different outcome for democracies as opposed to nondemocracies. Only about forty percent of non-democracies implement the distributive

\footnotetext{
${ }^{8}$ As shown in Tables A2-A4 in Appendix A, median voters turn out to significantly differ from median income earners in the respective countries and years.

${ }^{9}$ Table A5 in Appendix A reports the country-wave specific values of $\delta_{m}$.
} 
preferences of the (hypothetical) median voter. The average dissatisfaction of the median voter with political redistribution (average $\Delta_{m}$ ) equals about 1 in non-democracies as compared to only .6 in democracies.

The latter finding corroborates the view that the existence of democratic institutions is indeed a distinctive driver of a country's ability to cater to the will of the majority in terms of redistribution. The next section investigates more closely this claim by ascertaining whether the difference between democracies and non-democracies is statistically significant.

\section{Democracy and the Median Voter}

\subsection{Non-parametric tests}

We use various non-parametric tests to gauge the statistical relationship between democracy and the government's alignment with the distributional preferences of the median voter. Since our variables of interest are ordinal and not normally distributed, Spearman's rank correlation, Wilcoxon-Mann-Whitey test (also called Wilcoxon rank sum test), the Chisquared test (also known as Pearson's chi-squared test), and Fisher's exact test are the test statistics we focus on. ${ }^{10}$

Table 3. Median voter and democracy: Results from non-parametric tests

\begin{tabular}{c|cccc}
\hline$\Delta_{m}$ & & free_polity & polity_7 & free \\
\hline Spearman's & Coefficient & -0.1947 & -0.2050 & -0.1842 \\
& p-value & 0.0013 & 0.0007 & 0.0016 \\
Wilcoxon & p-value & 0.0014 & 0.0008 & 0.0017 \\
Chi-Squared & p-value & 0.012 & 0.007 & 0.017 \\
Fisher's exact & p-value & 0.008 & 0.004 & 0.012 \\
\hline
\end{tabular}

The results for our baseline specification of democracy appear in the first column of Table 3. Spearman's rank correlation between the dissatisfaction of the median voter - as measured by $\Delta_{m}$ - and democracy takes the value -.19 and is highly significant $(\mathrm{p}<.001)$. This indicates that democratic countries significantly differ from non-democratic countries in terms of their ability to implement the distributive policies preferred by the median voter.

\footnotetext{
${ }^{10}$ See e.g. Upton and Cook (2008).
} 
The Wilcoxon-Mann-Whitey test is used to test the hypothesis that two random variables are drawn from the same population. Employing the two-sample Wilcoxon rank-sum (MannWhitney) test, the hypothesis that the distribution of $\Delta_{m}$ is the same in democracies and nondemocracies is significantly rejected $(\mathrm{p}<.001)$.

The Chi-squared test of independence of two random variables clearly rejects the hypothesis that the median voter's dissatisfaction is statistically independent from the existence of a democratic political system in her country $(\mathrm{p}<.012)$. This result is confirmed by Fisher's exact test, a modification of Pearson's chi-squared test which puts fewer constraints on the data.

The second and the third columns in Table 3 report the corresponding test statistics for the definitions of democracy separately derived from the Polity IV and the Freedom House index, respectively. While correlation coefficients slightly decrease, they confirm the distinctive ability of democracies to implement the preferences of the median voter.

\subsection{Regression analysis}

We now investigate whether being a democracy significantly correlates with the extent to which the government caters to the preferences of the median voter in a logit model. Results from ordered logit regressions are shown in Table 4. Models (1) and (2) refer to our baseline definition of democracy and differ with respect to the inclusion of wave fixed effects. In both cases we find that a democratic political system significantly reduces the gap between actual redistribution and the one desired by the majority of the population. ${ }^{11}$ Models (3) and (4) employ the Polity IV definition of democracy and show that the effect of democracy is only slightly reduced. Models (5) and (6) use the Freedom House index of democracy and yield qualitatively similar results.

\footnotetext{
${ }^{11}$ Results are robust to the use of year dummies instead of wave dummies.
} 
Table 4. Ordered logit for median voter's disagreement with government.

\begin{tabular}{|c|c|c|c|c|c|c|}
\hline$\Delta_{m}$ & (1) & (2) & (3) & (4) & (5) & (6) \\
\hline free_polity & $\begin{array}{c}-0.752^{* *} \\
(-2.73)\end{array}$ & $\begin{array}{c}-0.814^{* *} \\
(-2.72)\end{array}$ & & & & \\
\hline polity_7 & & & $\begin{array}{l}-0.839^{* *} \\
(-2.84)\end{array}$ & $\begin{array}{c}-0.881^{* *} \\
(-2.79)\end{array}$ & & \\
\hline free & & & & & $\begin{array}{l}-0.714^{* *} \\
(-2.65)\end{array}$ & $\begin{array}{c}-0.792^{* *} \\
(-2.73)\end{array}$ \\
\hline $\begin{array}{c}\text { Wave } \\
\text { Dummies }\end{array}$ & & Yes & & Yes & & Yes \\
\hline $\mathrm{N}$ & 270 & 270 & 271 & 271 & 290 & 290 \\
\hline
\end{tabular}

$t$ statistics in parentheses; s.e. corrected for clustering at country level; cut-points not reported;

${ }^{+} p<0.10,{ }^{*} p<0.05,{ }^{* *} p<0.01,{ }^{* * *} p<0.001$

To the best of our knowledge, ours are the first empirical findings to show that over a large set of countries democracy positively correlates with the ability of the majority of the population to obtain from the government its preferred level of redistribution.

\subsection{Robustness checks}

In order to assess robustness we repeat the above analysis by employing the following alternative measures of democracy: a binary democracy measure computed by Boix et al. (2012) (democracy), the full Polity IV index ranging from -10 to +10 (polity), an indicator for democracies set equal to the most restrictive definition of democracy provided by Polity IV (democ_10), the full Freedom House index (freedom), an indicator for democracies set equal to the most restrictive definition of democracy provided by Freedom House (freedom_2) and a measure of democratization computed by Vanhanen (2003), van_index. ${ }^{12}$

Again, we find that redistributive policies are significantly better aligned to the median voter's preferences in more democratic countries. Table 5 offers an overview of our results for the non-parametric tests.

\footnotetext{
${ }^{12}$ See Appendix B1 for details on construction and distribution of all those democracy variables.
} 
Table 5. Non-parametric tests using alternative indicators of democracy

\begin{tabular}{c|ccccccc}
\hline$\Delta_{m}$ & & democracy & polity & democ_10 & freedom & freedom_2 & van_index \\
\hline Spearman's & Coef. & -0.2109 & -0.2847 & -0.2577 & -0.2589 & -0.2069 & -0.2601 \\
& -value & 0.0035 & 0.0000 & 0.0001 & 0.0000 & 0.0012 & 0.0000 \\
Wilcoxon & p-value & 0.0037 & $\mathrm{xxx}$ & 0.0001 & $\mathrm{xxx}$ & 0.0014 & $\mathrm{xxx}$ \\
Chi-Squared & p-value & 0.027 & 0.000 & 0.002 & 0.001 & 0.013 & $\mathrm{xxx}$ \\
Fisher's & p-value & 0.021 & $\mathrm{xxx}$ & 0.001 & $\mathrm{xxx}$ & 0.006 & $\mathrm{xxx}$ \\
\hline
\end{tabular}

xxx: polity, freedom and the van_index are non-binary measures so that Wilcoxon rank sum test and the Fisher exact test cannot be computed.

Table 6 reports the main estimation results for the above alternative measures of democracy in ordered logit regressions. As in case of Table 4, the results turn out to be robust to the inclusion of time dummies. They confirm the claim that more political democracy comes along with a higher probability that the government implements the redistributive preferences of the majority of the population.

Table 6. Ordered logit using alternative indicators of democracy

\begin{tabular}{|c|c|c|c|c|c|c|}
\hline$\Delta_{m}$ & (1) & (2) & (3) & (4) & (5) & (6) \\
\hline democracy & $\begin{array}{l}-0.956^{* *} \\
(-2.73)\end{array}$ & & & & & \\
\hline polity & & $\begin{array}{l}-0.058^{*} \\
(-2.07)\end{array}$ & & & & \\
\hline democ_10 & & & $\begin{array}{c}-0.990^{* * *} \\
(-3.35)\end{array}$ & & & \\
\hline freedom & & & & $\begin{array}{l}-0.100^{* *} \\
(-2.58)\end{array}$ & & \\
\hline freedom_2 & & & & & $\begin{array}{l}-0.684^{*} \\
(-2.51)\end{array}$ & \\
\hline van_index & & & & & & $\begin{array}{c}-0.045^{* * *} \\
(-3.66)\end{array}$ \\
\hline $\mathrm{N}$ & 191 & 270 & 270 & 290 & 290 & 245 \\
\hline
\end{tabular}

$t$ statistics in parentheses; s.e. corrected for clustering at country level; cut-points not reported; ${ }^{+} p<0.10,{ }^{*} p<0.05,{ }^{* *} p<0.01,{ }^{* * *} p<0.001$

In sum, our empirical strategy has hitherto produced two main insights. First, in their majority, democracies follow the rule of the majority, i.e. implement an amount of redistribution such that one half of the polity would like to reduce it and the other half would like to increase it. Second, democracies behave differently from non-democracies, i.e. are significantly more likely to implement the amount of redistribution that is preferred by the median voter. 


\subsection{Within-country evidence}

As mentioned above, in our sample most countries retain their status as democracy or non-democracy during the entire observation period, so that our results should be interpreted as conditional cross-country correlations. Unsurprisingly, introducing country fixed effects in the regressions of Tables 4 and 6 preserves the sign of the coefficients but statistical significance is lost.

In our sample, out of 110 countries only sixteen switch their democracy status and only ten of them are observed for at least half of the time, i.e. in four years. They include seven countries that made a single transition from non-democracy to democracy (Bulgaria, Estonia, South Korea, Peru, Poland, Romania and South Africa) and three countries that switched their political status twice during the observation period (India, Mexico and Ukraine). This yields a sufficiently small sample that can be explored in some detail.

Table 7 shows for the seven transition countries the average median voter's disagreement with the government before and after transition. Democracy was accompanied by a better alignment of redistribution with the preferences of the median voter in Bulgaria, Peru, Poland and South Africa, but not so in Estonia, South Korea and Romania.

Table 7. Average $\Delta_{m}$ before and after transition to democracy

\begin{tabular}{c|cc}
\hline country & $\overline{\Delta_{m}}$-pre & $\overline{\Delta_{m}}$-post \\
\hline Bulgaria & 1 & .75 \\
Estonia & 0 & 1 \\
South Korea & .5 & 1 \\
Peru & 2 & 1.33 \\
Poland & 2 & 1 \\
Romania & 1 & 1.4 \\
South Africa & 1 & 0 \\
\hline
\end{tabular}

The evidence with respect to the countries that switched twice is also somewhat mixed, see Table 8. In India, the political system was democratic in the initial and in the final part of the observation period. Those periods coincided with a much lower value of $\Delta_{m}$. In Mexico and Ukraine, the democratic period was the one in the middle. Only in Ukraine was this period one of relatively small median voter's dissatisfaction with governmental redistribution. 
Table 8. Average $\Delta_{m}$ across periods of transition to and from democracy

\begin{tabular}{c|c|ccc}
\hline \multirow{2}{*}{ India } & & $\begin{array}{c}\text { Wave 2 } \\
\text { (democracy) }\end{array}$ & $\begin{array}{c}\text { Wave 3 } \\
\text { (non-democracy) }\end{array}$ & $\begin{array}{c}\text { Waves 4 and 5 } \\
\text { (democracy) }\end{array}$ \\
\hline \multirow{3}{*}{ Mexico } & $\overline{\Delta_{m}}$ & 0 & 3 & 1 \\
\hline \multirow{2}{*}{ Ukraine } & $\overline{\Delta_{m}}$ & $\begin{array}{c}\text { Waves 2 and 3 } \\
\text { (non-democracy) }\end{array}$ & $\begin{array}{c}\text { Waves 4 and 5 } \\
\text { (democracy) }\end{array}$ & $\begin{array}{c}\text { Wave 7 } \\
\text { (non-democracy) }\end{array}$ \\
& & .5 & .5 & 0 \\
\hline
\end{tabular}

Taken together with the cross-country evidence, these findings suggest that democracies tend to implement the distributive preferences of the majority but forces exist that may prevent this from happening. Even when a country becomes a democracy there is no guarantee that the median voter may become more content with the amount of redistribution offered by the government. This raises the question what those forces are, a question that to which we now turn.

\section{Minority-backed Redistributions}

\subsection{Theoretical considerations}

Failure to implement the distributive preferences of the median voter may just mirror some policy delays in reacting to shocks that affect the distributive preferences of the electorate. But it may also result from systematic factors, and political economy offers some possible explanations as to why the level of redistribution in a democracy may be supported by only a minority of citizens. We examine two explanations that feature prominently in the literature and lend themselves to empirical scrutiny: asymmetric political participation and bundling of policy issues.

The first hypothesis grounds on the observation that electoral turnout and other forms of political participation are not evenly distributed in the population. As put forward e.g. by Bénabou (2000), if non-voters are not randomly distributed across the total population, the pivotal voter in the election does not coincide with the hypothetical median voter, i.e. the citizen whose preferred policy is the median in the set of all preferred policies in the population. In this case the government implements the distributive preferences of some 
effective - rather than hypothetical - median voter. If for instance poor people are less likely to vote, the effective median voter will be relatively rich and the outcome may be an amount of redistribution that is too limited from the viewpoint of the majority of citizens.

The second hypothesis is based on the observation that redistribution is not the only issue that determines how people vote in elections. As a rule, issues related to morals and rights are also at stake in electoral competitions. As shown by Roemer (1998), the presence of a second dimension in the political game entails a policy-bundle effect, implying that the median preference in the redistribution dimension generally fails to be implemented. If that second dimension of the electoral struggle - call it the values issue - is relatively salient, parties direct their efforts at winning the vote of those who are close to the median in the values dimension, as those voters are pivotal. Therefore, parties tend to propose redistributive policies that cater to the median voter in that dimension. As soon as the views on values are not independently distributed from the views on redistribution, the chosen level of redistribution will depart from the one that would have arisen had the values issue been absent. ${ }^{13}$

According to the asymmetric-participation theory, governments tend to implement the level of redistribution that is the median in the distribution of the corresponding peaks of the politically active population. According to the policy-bundle theory, governments tend to implement the distributional preferences of the median voter in the values dimension. This invites one to identify the distributional preferences that are pivotal according to each of those two theories and contrast them with the distributional preferences of the median voter in the redistribution dimension.

The asymmetric-participation theory predicts the following outcome: the larger the distance between the median distributive preferences of the politically active population and the distributive preferences of the (hypothetical) median voter in the redistribution dimension, the larger is the misalignment of actual redistribution from the level of redistribution preferred by the (hypothetical) median voter, i.e. the larger is $\Delta_{m}$. The policy-bundle theory generates the following prediction: the larger the distance between the mean ideal policy of the set of voters who hold the median position on the values issue and the ideal policy of the median voter in the redistribution dimension, the larger is $\Delta_{m}$. Both predictions can be evaluated with the data at hand. ${ }^{14}$

\footnotetext{
${ }^{13}$ Notice that the result may be either too little or too much redistribution - a point already stressed by Roemer (1998). Similarly, the asymmetric-participation theory allows for the possibility of too little redistribution e.g. in the case where political participation positively correlates with altruism towards the poor.

${ }^{14}$ An alternative way to assess the policy-bundle effect would be based on variations in the saliency of the values issues in the various countries and years. Unfortunately, no suitable variable for measuring saliency is available in our dataset.
} 


\subsection{Main empirical results}

The WVS contains the following survey question about voting that can be used to identify likely non-voters: "If there were an election tomorrow, for which party on this list would you vote?” In alternative to choosing a party, respondents had the possibility to state that they do not have the right to vote, or that they would not vote or cast a blank ballot. Respondents who chose one of those statements make up about $18 \%$ of the sample.

We retain the remaining $82 \%$ of the population as the effective voters. Based on this restricted sample, we compute again for each country/wave observation the median distributional preferences and denote them by $r_{p} \in\{1,2, \ldots, 10\}$. According to the asymmetricparticipation theory, we expect the distributional bias $\Delta_{m}$ to be increasing in $\left|r_{m}-r_{p}\right|$, where $r_{m}$ is the (hypothetical) median voter's preferred level of redistribution which we computed in sections 2 and 3 when comparing democracies with non-democracies.

With regard to the policy-bundle theory, the particular values issues that are prominent in elections are likely to exhibit much variability across countries and over time. However, research on value change in contemporary societies has established that conflicting views on particular values issues can often be traced back to a common dimension, namely the one opposing materialism to post-materialism. Post-materialistic values emphasize selfdetermination, self-expression and tolerance whereas materialistic values emphasize duty, authority and acceptance. Individuals greatly differ in their degree of post-materialism and such individual differences turn out to correlate with differences in attitudes towards a number of salient policy issues concerning e.g. abortion, delinquency, immigration and race. ${ }^{15}$ We exploit this insight to make the policy-bundle theory amenable to an empirical test.

The WVS attaches to each respondent an index-number of post-materialism that is obtained from the respondent's answers to three selected questions. Those questions ask about collective goals - like fighting crime and empowering people - and how the respondent prioritizes them. ${ }^{16}$ As a result, the respondent is assigned to one of six possible levels of postmaterialism.

\footnotetext{
${ }^{15}$ See e.g. Inglehart (1997) and applications to U.S. politics provided by Brown and Carmines (1995) and Knuckey (2005, 2007). Corneo and Jeanne (2009) propose an economic theory that identifies conditions under which some part of the population endogenously develops a taste for tolerance.

${ }^{16}$ For instance, one of those survey questions lists the following items: 'Maintaining order in the nation', 'Giving people more say in important government decisions', 'Fighting rising prices', 'Protecting freedom of speech'. More details about the construction of the post-materialism index and the determination of the distributive preferences of the median-values holders are provided in Appendix B4.
} 
We use that index of post-materialism to recover the distribution of values in the population. Then, we identify the individuals who endorse the median values in the various country/wave observations. Let their preferences for redistribution be denoted by $r_{v}$. The distributional bias due to the bundling of policy issues is expected to increase with $\left|r_{m}-r_{v}\right|$.

Table 9 presents results obtained by estimating ordered-logit regressions accounting for the deviation of the actual level of redistribution from the one preferred by the majority $\left(\Delta_{m}\right)$. Of course, only democracies are considered, i.e. observations for which free_polity $=1$. The specification in column (1) merely includes the asymmetric-participation effect. That is replaced in column (2) by the policy-bundle effect. Column (3) takes both effects into account. Column (4) adds wave dummies while column (5) adds region dummies. ${ }^{17}$ Column (6) controls for both.

Table 9. Ordered logit for the policy-bundle and the asymmetric-participation effect

\begin{tabular}{c|cccccc}
\hline$\Delta_{m}$ & $(1)$ & $(2)$ & $(3)$ & $(4)$ & $(5)$ & $(6)$ \\
\hline \multirow{3}{*}{$\left|r_{m}-r_{p}\right|$} & & & & & & \\
& 0.481 & & 1.038 & 0.878 & 0.896 & 0.709 \\
$\left|r_{m}-r_{v}\right|$ & $(0.83)$ & & $(0.81)$ & $(0.63)$ & $(0.68)$ & $(0.49)$ \\
& & $5.729^{* * *}$ & $5.572^{* * *}$ & $5.630^{* * *}$ & $5.655^{* * *}$ & $5.744^{* * *}$ \\
\multirow{2}{*}{ Wave Dummies } & & $(7.68)$ & $(7.66)$ & $(7.44)$ & $(7.58)$ & $(7.12)$ \\
Region Dummies & No & No & No & Yes & No & Yes \\
\hline \multirow{2}{*}{$N$} & 157 & No & No & No & Yes & Yes \\
\hline
\end{tabular}

$t$ statistics in parentheses; s.e. corrected for clustering at country level; cut-points not reported; ${ }^{+} p<0.10,{ }^{*} p<0.05,{ }^{* *} p<0.01,{ }^{* * *} p<0.001$

As shown in the Appendix (Tables A6-A7), voter turnout positively correlates with income and education. Nevertheless, we find that asymmetric political participation does not significantly contribute to explain the deviation of redistributive policy from the one preferred by the median voter - see the first row of Table 9. As reported in the Appendix (Table A8), the average $\left|r_{m}-r_{p}\right|$ is small, which mirrors the fact that in their demand for redistribution the richer and the more educated are also guided by non-pecuniary motives. This suggests that the

\footnotetext{
${ }^{17}$ Each country is assigned to one of the following regions: Anglosaxon, Latin America, Europe, Asia, Africa. An alternative partition into fifteen regions leaves all our estimation results qualitatively unaffected. Unfortunately, our dataset does not suffice to conduct estimations with country fixed effects, i.e. the estimation procedure does not converge. However, results obtained after 2,000 iterations are qualitatively similar to those in Table 9. They are available from the authors upon request.
} 
effect from asymmetric political participation is not powerful enough to significantly contribute to explain distributional biases in democracies.

The results in Table 9 lend instead considerable support to the policy-bundle theory. We find that the policy-bundle effect is strongly significant and the coefficient has the expected positive sign. This suggests that values issues crucially shape political competition in democracies and affect the amount of redistribution that is eventually provided by the government.

The policy-bundle effect turns out to be quantitatively of the first order: at sample means, decreasing $\left|r_{m}-r_{v}\right|$ from 1 to 0 increases the probability to implement the preferences of the median voter on the redistributive issue (i.e. to observe $\Delta_{m}=0$ ) from $5 \%$ to $95 \%$. In fact, simple inspection of the descriptive statistics reveals that median voters in the values dimension often get their preferred redistribution policy and are better served than median voters in the redistribution dimension. To be more precise, define $\Delta_{v}$ analogously to $\Delta_{m}$ as the distance separating the peak of the median in the distribution of values from the median categories of the question measuring the demand for redistribution. We find that in all country/years where redistribution does not accord with the will of the majority (i.e. $\Delta_{m}>0$ ), $\Delta_{v}$ is always smaller than $\Delta_{m} \cdot 18$

\subsection{Robustness checks}

The results in Table 9 are based on a sample that uses our preferred definition of democracy, obtained by combining the democracy indicators derived from Polity IV and the Freedom House datasets. Our results remain qualitatively unchanged if alternative definitions of democracy are employed - see Appendix C and D. We find that the policy-bundle effect systematically contributes to explain why democracies sometimes fail to implement the distributional preferences of the median voter. Asymmetric political participation entails instead at most a second-order effect.

The estimations presented in Table 9 only control for time and region, which are obviously exogenous to the working of democracy. We have then performed additional regressions that control for a bunch of macroeconomic variables, including log of per-capita

\footnotetext{
${ }^{18}$ Our results are consistent with previous findings showing that values issues can significantly affect the amount of redistribution in democracies. Roemer and Van der Straeten (2005) offer a simulation exercise based on French data which suggests that xenophobia had a substantial effect on the economic policies proposed by political parties at the presidential elections in the period 1988-2002. Alesina et al. (2001) and Lee and Roemer (2006) provide evidence on the effect of racism on redistribution in the United States.
} 
GDP in constant dollars and PPP, GDP growth rate, inflation rate, unemployment rate, Gini coefficient of the income distribution (both pre-fisc and post-fisc), tax revenue as a fraction of GDP, government debt, public deficit, and openness. Also in that case, the results from Table 9 on the asymmetric-participation theory and the policy-bundle theory remain qualitatively unaffected. The same applies once one controls for ethnic fractionalization, religious attendance, electoral system, and quality of government. ${ }^{19}$

With regard to the asymmetric-participation theory, a potential source of concern about the results in Table 9 is that the proxy we used identifies merely 18\% of respondents as nonvoters. Actual turnout rates suggest the non-voting population to be substantially larger in most democracies.

As a robustness check, we now switch to an alternative survey question of the WVS about political interest. People were asked whether they are very interested in politics, somewhat interested, not very interested, or not at all interested. We employ the latter category to identify persons who are likely to have no political influence. This accounts for about $22 \%$ of the sample, which is more in line with turnout rates. We retain the remaining $78 \%$ of the population as the politically active one. Based on this restricted sample, we compute again for each country/wave observation the median distributional preferences and denote them by $r_{p}^{\prime} \in\{1,2, \ldots, 10\}$. The distributional bias due to asymmetric political participation is again expected to be increasing in $\left|r_{m}-r_{p}^{\prime}\right|$.

The results from this exercise are displayed in Table 10 (first row) and are similar to those in Table 9. Results remain qualitatively the same if we define the politically active population as the respondents who declared to be at least somewhat interested in politics - which excludes $52 \%$ of the sample.

\footnotetext{
${ }^{19}$ Estimation results are available from the authors upon request.
} 
Table 10. Ordered logits with an alternative proxy for the asymmetric-participation effect

\begin{tabular}{c|cccccc}
\hline$\Delta_{m}$ & $(1)$ & $(2)$ & $(3)$ & $(4)$ & $(5)$ & (6) \\
\hline \multirow{3}{*}{$\left|r_{m}-r_{p}^{\prime}\right|$} & & & & & & \\
& -0.138 & & 0.891 & 0.698 & 0.813 & 0.466 \\
$\left|r_{m}-r_{v}\right|$ & $(-0.23)$ & & $(0.73)$ & $(0.53)$ & $(0.64)$ & $(0.32)$ \\
& & $5.729^{* * *}$ & $5.809^{* * *}$ & $5.807^{* * *}$ & $5.959^{* * *}$ & $5.988^{* * * *}$ \\
Wave Dummies & & $(7.68)$ & $(7.61)$ & $(7.49)$ & $(7.33)$ & $(7.11)$ \\
Region Dummies & No & No & No & Yes & No & Yes \\
\hline \multirow{2}{*}{$N$} & 160 & No & No & No & Yes & Yes \\
\hline
\end{tabular}

$t$ statistics in parentheses; s.e. corrected for clustering at country level; cut-points not reported;

${ }^{+} p<0.10,{ }^{*} p<0.05,{ }^{* *} p<0.01,{ }^{* * *} p<0.001$

With regard to the policy-bundle theory, one might be concerned that our proxy is not available for about one third of the sample, so that we lose many observations when we use it. As a robustness check, we alternatively employ survey questions about distinct values issues that are available for most countries and waves of the WVS. Specifically, people were asked whether abortion, homosexuality and divorce are justifiable. For each of those three issues, respondents could choose in a 1-10 scale indicating their level of acceptance.

Table 11. Ordered logits with an alternative proxy for the policy-bundle effect

\begin{tabular}{c|cccccc}
\hline$\Delta_{m}$ & $(1)$ & $(2)$ & $(3)$ & $(4)$ & (5) & (6) \\
\hline \multirow{3}{*}{$\left|r_{m}-r_{p}\right|$} & & & & & & \\
& 0.481 & & 0.255 & 0.126 & 0.211 & 0.116 \\
$\left|r_{m}-r_{v}^{\prime}\right|$ & $(0.83)$ & & $(0.29)$ & $(0.14)$ & $(0.23)$ & $(0.12)$ \\
& & $5.174^{* * *}$ & $5.108^{* * *}$ & $5.197^{* * *}$ & $5.209^{* * *}$ & $5.274^{* * *}$ \\
Wave Dummies & & $(8.96)$ & $(8.74)$ & $(8.14)$ & $(8.28)$ & $(7.94)$ \\
Region Dummies & No & No & No & Yes & No & Yes \\
\hline \multirow{2}{*}{$N$} & 157 & 161 & 155 & 155 & 155 & 155 \\
\hline
\end{tabular}

$t$ statistics in parentheses; s.e. corrected for clustering at country level; cut-points not reported;

${ }^{+} p<0.10,{ }^{*} p<0.05,{ }^{* *} p<0.01,{ }^{* * *} p<0.001$

For each of those items we have replicated the procedure described above for the index of post-materialism in order to compute the redistributive views of the median-values holders. Then, we have conducted a regression analysis along the lines of Table 9. Our results are 
displayed in Table 11 for the case of values derived from respondents' attitudes towards abortion (second row). The Appendix exhibits our results for the cases of homosexuality and divorce (Tables A9 and A10). The number of observations that enter the analysis increases from 95 to 161. Results remain qualitatively unaffected, and this applies also to the marginal effects which remain strong. Overall, the policy-bundle theory receives a remarkable support from the data.

\section{Conclusion}

Since its very beginnings, the introduction of democracy has been accompanied by hopes and fears concerning the extent to which it would promote political redistribution and a more egalitarian distribution of income. Up to these days, an intensive debate has been conducted as to whether redistribution in democracies really follows the will of the majority or is rather captured by groups of the population, like the rich, who are better able to coordinate themselves and are in a position to exert disproportionate political influence. In this paper we have empirically investigated that issue by recovering from international survey data the alignment of actual redistribution with the one demanded by the median voter.

We have found two main results. First, under democracy in the majority of cases the median voter gets what she wants in terms of redistribution - i.e. the actual level of redistribution is backed by a majority of citizens against any alternative amount. Moreover, the ability of serving the median voter significantly distinguishes democratic countries from non-democratic countries and the higher is the quality of democracy, the higher is the probability that the median voter is served in terms of redistribution. Still, even in the group of countries with democratic political institutions the alignment of the government to the will of the majority is far from perfect.

Second, we have shed light on the empirical relevance of two mechanisms that may generate an amount of redistribution that is not the one demanded by the majority of the population. We have found that despite the rich and more educated being more likely to participate in politics, this asymmetry in political participation does not constitute a key driving force behind minority-backed levels of redistribution. Rather, the latter can be ascribed to the use of redistributive policy as a device to attract voters who are pivotal in settling values issues - concerning e.g. abortion and homosexuality. We have found that this policy-bundle effect substantially contributes to explain the misalignment of governmental redistribution from the will of the majority in about forty percent of the democracies in our 
sample. From the viewpoint of the median voter on the redistributive issue, this effect leads in some cases to an underprovision of redistribution while in others it entails an overprovision of redistribution.

To sum up, the median-voter theorem is in a first approximation an acceptable description of how redistribution is determined in democracies, provided the theorem is not unduly restricted to assume voters who are guided by pecuniary motives only. But a non-negligible share of democracies violates the prediction of the theorem and implements some minoritybacked redistributive policy. Those deviations can to a large extent be explained by a policybundle effect. Thus, understanding why such an effect matters in some contexts but not in others seems to be a promising question for future research on political redistribution.

\section{Acknowledgements}

We have benefited from the comments of participants at seminars and conferences in Berlin, Bratislava, Cambridge, Milan, Paris, Pavia, Venice and Warsaw. Financial support from the Deutsche Forschungsgemeinschaft through SFB/TR 15 is gratefully acknowledged. 


\section{References}

Acemoglu, D., Naidu, S., Restrepo, P. \& Robinson, J. (2013). Democracy, redistribution and inequality. NBER WP 19746.

Alesina, A., \& Angeletos, G. M. (2005). Fairness and redistribution. American Economic Review, 960-980.

Alesina A. \& P. Giuliano (2010). Preferences for redistribution, in Handbook of Social Economics, Vol. 1A, edited by J. Benhabib, M. Jackson, A. Bisin, Elsevier.

Alesina, A., Glaeser, E., Sacerdote, B. (2001). Why doesn't the US have a European-style welfare state? Brookings Papers on Economic Activity 2, 187-254.

Alesina, A., \& La Ferrara, E. (2005). Preferences for redistribution in the land of opportunities. Journal of Public Economics, 89(5), 897-931.

Alesina, A., \& Rodrik, D. (1994). Distributive politics and economic growth. The Quarterly Journal of Economics, 109(2), 465-490.

Barro, R. J. (1999). Determinants of democracy. Journal of Political Economy, 107(S6), 158183.

Bartels, L. M. (2008). Unequal Democracy: The Political Economy of the New Gilded Age. Princeton: Princeton University Press.

Beck, T., Clarke, G., Groff, A., Keefer, P., \& Walsh, P. (2001). New tools in comparative political economy: The Database of Political Institutions. The World Bank Economic Review, 15(1), 165-176.

Boix, C., Miller, M., \& Rosato, S. (2012). A Complete Data Set of Political Regimes, 18002007. Comparative Political Studies.

Benabou, R. (2000). Unequal societies: Income distribution and the social contract. American Economic Review, 96-129.

Benabou, R. and E. Ok (2001), Mobility and the demand for redistribution: The POUM hypothesis. The Quarterly Journal of Economics, 116(2), 447-487.

Benabou, R., \& Tirole, J. (2006). Belief in a just world and redistributive politics. The Quarterly Journal of Economics, 121(2), 699-746.

Bernasconi, M. (2006). Redistributive taxation in democracies: Evidence on people's satisfaction. European Journal of Political Economy, 22(4), 809-837.

Bonica, A., McCarty, N., Poole, K. T., \& Rosenthal, H. (2013). Why hasn't democracy slowed rising inequality? The Journal of Economic Perspectives, 27(3), 103-123.

Brown, R. D., \& Carmines, E. G. (1995). Materialists, postmaterialists, and the criteria for political choice in US presidential elections. The Journal of Politics, 57(02), 483-494. 
Brückner, M., \& Ciccone, A. (2011). Rain and the democratic window of opportunity. Econometrica, 79(3), 923-947.

Casper, G., \& Tufis, C. (2003). Correlation versus interchangeability: the limited robustness of empirical findings on democracy using highly correlated datasets. Political Analysis, 11, 196-203.

Corneo, G., \& Grüner, H. P. (2000). Social limits to redistribution. The American Economic Review, 90(5), 1491-1507.

Corneo, G., \& Grüner, H. P. (2002). Individual preferences for political redistribution. Journal of Public Economics, 83(1), 83-107.

Corneo, G., \& Jeanne, O. (2009). A theory of tolerance. Journal of Public Economics, 93, 691-702.

Dahlberg, M., Edmark, K. \& H. Lundqvist (2012). Ethnic diversity and preferences for redistribution. Journal of Political Economy, 120, 41-76.

Engelhardt, C. \& Wagener, A. (2014). Biased Perception of Income Inequality and Redistribution. Mimeo.

EVS (2011). European Values Study 2008: Integrated Dataset. GESIS Data Archive, Cologne. ZA4800 Data file version 3.0.0, doi:10.4232/1.11004

Fong, C. (2001). Social preferences, self-interest, and the demand for redistribution. Journal of Public Economics, 82(2), 225-246.

Georgiadis, A., \& Manning, A. (2012). Spend it like Beckham? Inequality and redistribution in the UK, 1983-2004. Public Choice, 151(3-4), 537-563.

Höchtl, W., Sausgruber, R. \& Tyran, J.-R. (2012). Inequality aversion and voting on redistribution. European Economic Review 56, 1406-1421.

Inglehart, R. (1997). Modernization and Postmodernization. Princeton University Press, Princeton.

Klor, E. F., \& Shayo, M. (2010). Social identity and preferences over redistribution. Journal of Public Economics, 94(3), 269-278.

Knuckey, J. (2005). A new front in the culture war? Moral traditionalism and voting behavior in US House elections. American Politics Research, 33(5), 645-671.

Knuckey, J. (2007). Moral values and vote choice in the 2004 US presidential election. Politics \& Policy, 35(2), 222-245.

Lee, W., \& Roemer, J. E. (2006). Racism and redistribution in the United States: A solution to the problem of American exceptionalism. Journal of Public Economics, 90(6), 1027-1052.

Lindbeck, A., Nyberg, S., \& Weibull, J. W. (1999). Social norms and economic incentives in the welfare state. The Quarterly Journal of Economics, 114(1), 1-35. 
Luttmer, E. F. (2001). Group loyalty and the taste for redistribution. Journal of Political Economy, 109(3), 500-528.

Luttmer, E. F., \& Singhal, M. (2011). Culture, context, and the taste for redistribution. American Economic Journal: Economic Policy, 3(1), 157-179.

Marshall, M. G., Gurr, T. \& Jaggers, K. (2013). Polity IV Dataset and Users' Manual: Political Regime Characteristics and Transitions, 1800 - 2012. (http://www.systemicpeace.org/inscr/p4manualv2012.pdf)

Meltzer, A. H., \& Richard, S. F. (1981). A rational theory of the size of government. The Journal of Political Economy, 914-927.

Milanovic, B. (2000). The median-voter hypothesis, income inequality, and income redistribution: an empirical test with the required data. European Journal of Political Economy, 16(3), 367-410.

Munck, G. L., \& Verkuilen, J. (2002). Conceptualizing and measuring democracy Evaluating alternative indices. Comparative Political Studies, 35(1), 5-34.

Murthi, M., \& Tiongson, E. R. (2009). Attitudes to income equality: the 'socialist legacy' revisited. Comparative Economic Studies, 51(3), 344-366.

Osberg, L., \& Smeeding, T. (2006). "Fair” inequality? Attitudes toward pay differentials: the United States in comparative perspective. American Sociological Review, 71(3), 450-473.

Perotti, R. (1996). Growth, income distribution, and democracy: what the data say. Journal of Economic Growth, 1(2), 149-187.

Persson, T., \& Tabellini, G. (1994). Is inequality harmful for growth?. American Economic Review 84, 600-621.

Piketty, T. (1995). Social mobility and redistributive politics. The Quarterly Journal of Economics, 110(3), 551-584.

Ravallion, M., \& Lokshin, M. (2000). Who wants to redistribute? The tunnel effect in 1990s Russia. Journal of Public Economics, 76(1), 87-104.

Roberts, K.W.S. (1977), Voting over income tax schedules. Journal of Public Economics 8: $329-340$

Romer, T. (1975), Individual welfare, majority voting, and the properties of a linear income tax. Journal of Public Economics 4, 163-85.

Roemer, J. E. (1998). Why the poor do not expropriate the rich: an old argument in new garb. Journal of Public Economics, 70(3), 399-424.

Roemer, J. E. (2001). Political Competition: Theory and Applications. Harvard University Press. 
Roemer, J. E., \& Van der Straeten, K. (2005). Xenophobia and the size of the public sector in France: A politico-economic analysis. Journal of Economics, 86(2), 95-144.

Scervini, F. (2012). Empirics of the median voter: democracy, redistribution and the role of the middle class. The Journal of Economic Inequality, 10(4), 529-550.

Shayo, M. (2009). A model of social identity with an application to political economy: Nation, class, and redistribution. American Political Science Review, 103(2), 147-174.

Tyran, J.-R. \& Sausgruber, R. (2006). A little fairness may induce a lot of redistribution in democracy. European Economic Review 50, 469-485.

World Bank (2012). World Bank Development Indicators 2012.

WVS (2006). European and World Values Surveys four-wave integrated data file, 1981-2004, v.20060423, 2006. Surveys designed and executed by the European Values Study Group and World Values Survey Association. File Producers: ASEP/JDS, Madrid, Spain and Tilburg University, Tilburg, the Netherlands. File Distributors: ASEP/JDS and GESIS, Cologne, Germany.

WVS (2009). WORLD VALUES SURVEY 1981-2008 OFFICIAL AGGREGATE v.20090901, 2009. World Values Survey Association (www.worldvaluessurvey.org). Aggregate File Producer: ASEP/JDS, Madrid.

Upton, G., \& Cook, I. (2008). A Dictionary of Statistics. Oxford University Press.

Vanhanen, T. (2003). Measures of Democracy 1810-2002. Finnish Social Science Data Archive. 


\section{Appendix}

\section{Appendix A: Descriptive Statistics and Re-estimation of Table 11}

Table A1. Frequency distribution of preferences for redistribution; all countries.

\begin{tabular}{c|ccc}
\hline equal_income & Freq. & Percent & Cum. \\
\hline $\begin{array}{c}\text { incomes more } \\
\text { equal }\end{array}$ & & & \\
2 & 52,438 & 13.61 & 13.61 \\
3 & 22,839 & 5.93 & 19.53 \\
4 & 30,516 & 7.92 & 27.45 \\
5 & 26,749 & 6.94 & 34.39 \\
6 & 49,622 & 12.88 & 47.27 \\
7 & 32,889 & 8.53 & 55.80 \\
8 & 39,784 & 10.32 & 66.12 \\
9 & 48,845 & 12.67 & 78.80 \\
incentives to & 26,272 & 6.82 & 85.61 \\
individual efforts & 55,453 & 14.39 & 100.00 \\
& & & \\
Total & 385,407 & 100.00 & \\
\hline
\end{tabular}

Table A2. Number and fraction of median-income-category-earners and median respondents

\begin{tabular}{|c|c|c|c|}
\hline & \multicolumn{2}{|c|}{ Median income earner } & Total \\
\hline $\begin{array}{l}\text { Median } \\
\text { respondent }\end{array}$ & 1 & 0 & \\
\hline \multirow[t]{2}{*}{0} & 70,293 & 263,222 & 333,515 \\
\hline & 21.08 & 78.92 & 100.00 \\
\hline \multirow[t]{2}{*}{1} & 11,595 & 41,761 & 53,356 \\
\hline & 21.73 & 78.27 & 100.00 \\
\hline \multirow[t]{2}{*}{ Total } & 81,888 & 304,983 & 386,871 \\
\hline & 21.17 & 78.83 & 100.00 \\
\hline
\end{tabular}

Table A3. Number and fraction of median respondents across income quintiles.

\begin{tabular}{|c|c|c|c|}
\hline & \multicolumn{2}{|c|}{ Median Respondent } & Total \\
\hline Income Quintal & 1 & 0 & \\
\hline \multirow[t]{2}{*}{1} & 12,208 & 79,919 & 92,127 \\
\hline & 13.25 & 86.75 & 100.00 \\
\hline \multirow[t]{2}{*}{2} & 8,836 & 55,797 & 64,633 \\
\hline & 13.67 & 86.33 & 100.00 \\
\hline \multirow[t]{2}{*}{3} & 8,063 & 48,876 & 56,939 \\
\hline & 14.16 & 85.84 & 100.00 \\
\hline \multirow[t]{2}{*}{4} & 7,976 & 46,570 & 54,546 \\
\hline & 14.62 & 85.38 & 100.00 \\
\hline
\end{tabular}




\begin{tabular}{c|ccc}
\hline 5 & 6,109 & 38,021 & 44,130 \\
& 13.84 & 86.16 & 100.00 \\
\hline Total & 43,192 & 269,183 & 312,375 \\
& 13.83 & 86.17 & 100 \\
\hline
\end{tabular}

Table A4. Number and fraction of median-income-category-earners by normalized distance to the indifference position.

\begin{tabular}{|c|c|c|c|}
\hline \multirow[b]{2}{*}{$\Delta_{i}$} & \multicolumn{2}{|c|}{ Median income earner } & \multirow[t]{2}{*}{ Total } \\
\hline & 1 & 0 & \\
\hline \multirow[t]{2}{*}{0} & 13,608 & 50,553 & 64,161 \\
\hline & 21.21 & 78.79 & 100.00 \\
\hline \multirow[t]{2}{*}{1} & 11,365 & 42,732 & 54,097 \\
\hline & 21.01 & 78.99 & 100.00 \\
\hline \multirow[t]{2}{*}{2} & 13,543 & 51,771 & 65,314 \\
\hline & 20.74 & 79.26 & 100.00 \\
\hline \multirow[t]{2}{*}{3} & 8,434 & 31,734 & 40,168 \\
\hline & 21.0 & 79.0 & 100.00 \\
\hline \multirow[t]{2}{*}{4} & 18,855 & 69,780 & 88,635 \\
\hline & 21.27 & 78.73 & 100.00 \\
\hline \multirow[t]{2}{*}{ Total } & 65,805 & 246,570 & 312,375 \\
\hline & 21.07 & 78.93 & 100.00 \\
\hline
\end{tabular}

Table A5. $\delta_{m}$ by country and wave

\begin{tabular}{|c|c|c|c|c|c|c|c|}
\hline country & 2 & 3 & 4 & 5 & 6 & 7 & Average \\
\hline Albania & . & 0 & 0 & . & 0 & . & 0 \\
\hline Algeria & . & . & 3 & . & . & 1 & 2 \\
\hline Andorra & . & . & . & 1 & . & . & 1 \\
\hline Argentina & 2 & 0 & 0 & 0 & . & 0 & .4 \\
\hline Armenia & . & 1 & . & . & 1 & 0 & .667 \\
\hline Australia & . & 0 & . & 0 & . & 0 & 0 \\
\hline Austria & 0 & . & -1 & . & -2 & . & -1 \\
\hline Azerbaijan & . & 0 & . & . & 0 & 0 & 0 \\
\hline Bangladesh & . & 2 & 2 & . & . & . & 2 \\
\hline Belarus & 2 & 1 & 0 & . & 0 & 0 & .6 \\
\hline Belgium & 0 & . & 0 & . & 0 & . & 0 \\
\hline Bosnia-Herzigovina & . & 0 & 0 & . & -1 & . & -.333 \\
\hline Brazil & 0 & 0 & . & 0 & . & . & 0 \\
\hline Bulgaria & 1 & 0 & 1 & 0 & 2 & . & .8 \\
\hline Burkina Faso & . & . & . & 2 & . & . & 2 \\
\hline Canada & 2 & . & 0 & 0 & . & . & .667 \\
\hline Chile & 0 & 0 & -2 & 0 & . & -2 & -.8 \\
\hline China & 2 & 0 & 1 & 0 & . & -1 & .4 \\
\hline Colombia & . & 1 & . & 0 & . & 0 & .333 \\
\hline Croatia & & 0 & 0 & 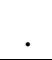 & -1 & . & -.333 \\
\hline
\end{tabular}




\begin{tabular}{|c|c|c|c|c|c|c|c|}
\hline Cyprus & . & . & . & 0 & 0 & -2 & -.667 \\
\hline Czech Republic & 2 & 1 & 0 & . & -1 & . & .5 \\
\hline Denmark & 1 & . & . & . & 1 & . & 1 \\
\hline Dominican Republic & . & 3 & . & . & . & . & 3 \\
\hline Ecuador & . & . & . & . & . & 0 & 0 \\
\hline Egypt & . & . & 3 & 1 & . & -2 & .667 \\
\hline El Salvador & . & 2 & . & . & . & . & 2 \\
\hline Estonia & 2 & 0 & 1 & . & 0 & -2 & .2 \\
\hline Ethiopia & . & . & . & 1 & . & . & 1 \\
\hline Finland & 1 & -1 & -1 & 0 & -1 & . & -.4 \\
\hline France & 0 & . & 0 & 0 & 0 & . & 0 \\
\hline Georgia & . & 2 & . & 2 & 3 & . & 2.333 \\
\hline Germany & 2 & 0 & . & -1 & -2 & -1 & -.4 \\
\hline Ghana & . & . & . & 3 & . & 2 & 2.5 \\
\hline Greece & . & . & . & . & -1 & . & -1 \\
\hline Guatemala & . & . & . & 2 & . & . & 2 \\
\hline Hong Kong & . & . & . & -1 & . & . & -1 \\
\hline Hungary & 0 & -2 & . & . & 0 & . & -.667 \\
\hline Iceland & 0 & . & 0 & . & 0 & . & 0 \\
\hline India & 0 & -3 & -2 & 0 & . & . & -1.25 \\
\hline Indonesia & . & . & 1 & 2 & . & . & 1.5 \\
\hline Iran & . & . & 0 & -2 & . & . & -1 \\
\hline Iraq & . & . & 0 & . & . & 0 & 0 \\
\hline Ireland & 1 & . & 1 & . & 0 & . & .667 \\
\hline Israel & . & . & -3 & . & . & . & -3 \\
\hline Italy & 0 & . & 0 & 0 & 0 & . & 0 \\
\hline Japan & 0 & 0 & 0 & 0 & . & 0 & 0 \\
\hline Jordan & . & . & 2 & 3 & . & 2 & 2.333 \\
\hline Kazakhstan & . & . & . & . & . & 0 & 0 \\
\hline Korea South & 0 & 1 & 1 & 1 & . & 1 & .8 \\
\hline Kyrgyz Republic & . & . & 0 & . & . & 0 & 0 \\
\hline Latvia & 2 & 1 & . & . & 1 & . & 1.333 \\
\hline Lebanon & . & . & . & . & . & 0 & 0 \\
\hline Libya & . & . & . & . & . & 2 & 2 \\
\hline Lithuania & 2 & 0 & 0 & . & 0 & . & .5 \\
\hline Luxembourg & . & . & 1 & . & 1 & . & 1 \\
\hline Macedonia & . & 0 & 0 & . & 2 & . & .667 \\
\hline Malaysia & . & . & . & 1 & . & 1 & 1 \\
\hline Mali & . & . & . & 3 & . & . & 3 \\
\hline Malta & 3 & . & . & . & 1 & . & 2 \\
\hline Mexico & 1 & 0 & 0 & 1 & . & 0 & .4 \\
\hline Moldova & . & 2 & 1 & 0 & 0 & . & .75 \\
\hline Montenegro & . & . & . & . & 0 & . & 0 \\
\hline Morocco & . & . & 4 & 0 & . & 0 & 1.333 \\
\hline Netherlands & 1 & . & 1 & 0 & 0 & 0 & .4 \\
\hline New Zealand & . & 0 & . & 0 & . & 0 & 0 \\
\hline Nigeria & 3 & 2 & 1 & & . & 1 & 1.75 \\
\hline
\end{tabular}




\begin{tabular}{|c|c|c|c|c|c|c|c|}
\hline Norway & 0 & 0 & . & 0 & 0 & . & 0 \\
\hline Pakistan & . & 2 & -1 & . & . & 1 & .667 \\
\hline Peru & . & 2 & 2 & 2 & . & 0 & 1.5 \\
\hline Philippines & . & 0 & 1 & . & . & 1 & .667 \\
\hline Poland & 2 & 2 & 1 & 1 & 0 & 1 & 1.167 \\
\hline Portugal & -1 & . & . & . & 0 & . & -.5 \\
\hline Qatar & . & . & . & . & . & 1 & 1 \\
\hline Romania & 1 & 1 & -2 & -1 & -2 & 1 & -.333 \\
\hline Russia & 1 & 1 & 2 & 1 & 1 & -2 & .667 \\
\hline Rwanda & . & . & . & 0 & . & -1 & -.5 \\
\hline Saudi Arabia & . & . & 1 & . & . & . & 1 \\
\hline Serbia & . & . & . & 0 & 0 & . & 0 \\
\hline Singapore & . & . & 2 & . & . & 0 & 1 \\
\hline Slovakia & 1 & 0 & . & . & 0 & . & .333 \\
\hline Slovenia & 0 & 0 & -1 & 0 & -2 & -2 & -.833 \\
\hline South Africa & 1 & 0 & 0 & 0 & . & 0 & .2 \\
\hline Spain & 0 & 0 & 0 & 0 & 0 & 0 & 0 \\
\hline Sweden & 1 & 0 & . & 1 & 0 & 0 & .4 \\
\hline Switzerland & . & 0 & . & -2 & -1 & . & -1 \\
\hline Taiwan & . & 0 & . & 1 & . & 0 & .333 \\
\hline Thailand & . & . & . & 1 & . & 0 & .5 \\
\hline Tunisia & . & . & . & . & . & 0 & 0 \\
\hline Turkey & -1 & 0 & -2 & 0 & 0 & -1 & -.667 \\
\hline Uganda & . & . & 3 & . & . & . & 3 \\
\hline Ukraine & . & 1 & 3 & 1 & 2 & -2 & 1 \\
\hline United Kingdom & 1 & 0 & 0 & 0 & 0 & . & .2 \\
\hline United States & 1 & 0 & 0 & 0 & . & 0 & .2 \\
\hline Uruguay & . & 0 & . & 0 & . & 0 & 0 \\
\hline Uzbekistan & . & . & . & . & . & -1 & -1 \\
\hline Venezuela & . & 0 & 0 & . & . & . & 0 \\
\hline Vietnam & . & . & 0 & 0 & . & . & 0 \\
\hline Zambia & . & . & . & 1 & . & . & 1 \\
\hline Zimbabwe & . & . & 2 & . & . & 1 & 1.5 \\
\hline Total & .929 & .426 & .475 & .482 & 0 & .0181 & .380 \\
\hline
\end{tabular}

Table A6. Share of political participation by income quintile (in Democracies)

\begin{tabular}{c|cccccc}
\hline & 1 & 2 & 3 & 4 & 5 & Average \\
\hline Voting & 80.98 & 81.68 & 82.40 & 82.94 & 83.96 & 82.17 \\
Not voting & 19.02 & 18.32 & 17.60 & 17.06 & 16.04 & 17.83 \\
\hline $\begin{array}{c}\text { Very interested } \\
\text { Somewhat, not very, } \\
\text { not at all interested }\end{array}$ & 74.15 & 77.70 & 80.18 & 82.00 & 84.15 & 78.80 \\
\hline $\begin{array}{c}\text { Very, somewhat } \\
\text { interested }\end{array}$ & 43.11 & 46.55 & 48.34 & 51.87 & 56.07 & 48.19 \\
$\begin{array}{c}\text { Not very, not at all } \\
\text { interested }\end{array}$ & 56.89 & 53.45 & 51.66 & 48.13 & 43.93 & 51.81 \\
\hline
\end{tabular}


Table A7. Share of political participation by education (in Democracies)

\begin{tabular}{c|cccc}
\hline & Primary & Some Sec. & Secondary & University \\
\hline Voting & 80.81 & 80.86 & 79.78 & 85.53 \\
Not voting & 19.19 & 19.14 & 20.22 & 14.47 \\
\hline $\begin{array}{c}\text { Very interested } \\
\text { Somewhat, not very, } \\
\text { not at all interested }\end{array}$ & 71.80 & 78.59 & 81.46 & 87.45 \\
\hline $\begin{array}{c}\text { Very, somewhat } \\
\text { interested }\end{array}$ & 41.60 & 45.99 & 49.35 & 58.73 \\
$\begin{array}{c}\text { Not very, not at all } \\
\text { interested }\end{array}$ & 58.40 & 54.01 & 50.65 & 41.27 \\
\hline
\end{tabular}

Table A8. Summary statistics of all central variables.

\begin{tabular}{|c|c|c|c|c|c|}
\hline Variable & Obs & Mean & Std. Dev. & Min & Max \\
\hline$\delta_{m}$ & 270 & 0.326 & 1.130 & -3 & 4 \\
\hline$\Delta_{m}$ & 270 & 0.756 & 0.900 & 0 & 4 \\
\hline \multicolumn{6}{|l|}{ Policy Bundle } \\
\hline$\left|r_{m}-r_{v}\right|$ (post-materialism) & 95 & 0.423 & 0.364 & 0.010 & 1.86 \\
\hline$\left|r_{m}-r_{v}^{\prime}\right|$ (abortion) & 161 & 0.450 & 0.361 & 0 & 1.856 \\
\hline$\left|r_{m}-\hat{r}_{v}\right|$ (homosexuality) & 161 & 0.489 & 0.394 & 0 & 1.842 \\
\hline$\left|r_{m}-\tilde{r}_{v}\right|($ divorce) & 162 & 0.438 & 0.398 & 0 & 2.2 \\
\hline \multicolumn{6}{|l|}{ Political Participation } \\
\hline$\left|r_{m}-r_{p}\right|$ (no vote) & 157 & 0.108 & 0.307 & 0 & 1 \\
\hline$\left|r_{m}-r_{p}^{\prime}\right|$ (no interest) & 160 & 0.106 & 0.304 & 0 & 1 \\
\hline$\left|r_{m}-r_{p}^{\prime \prime}\right|$ (no interest2) & 160 & 0.188 & 0.388 & 0 & 1 \\
\hline \multicolumn{6}{|l|}{ Wave Dummies } \\
\hline Wave 2 & 270 & 0.119 & 0.324 & 0 & 1 \\
\hline Wave 3 & 270 & 0.185 & 0.389 & 0 & 1 \\
\hline Wave 4 & 270 & 0.200 & 0.401 & 0 & 1 \\
\hline Wave 5 & 270 & 0.196 & 0.398 & 0 & 1 \\
\hline Wave 6 & 270 & 0.152 & 0.360 & 0 & 1 \\
\hline Wave 7 & 270 & 0.148 & 0.356 & 0 & 1 \\
\hline \multicolumn{6}{|l|}{ Region Dummies } \\
\hline Europe & 270 & 0.511 & 0.501 & 0 & 1 \\
\hline Asia & 270 & 0.2 & 0.401 & 0 & 1 \\
\hline Anglos-Saxon & 270 & 0.082 & 0.274 & 0 & 1 \\
\hline Latin-America & 270 & 0.115 & 0.319 & 0 & 1 \\
\hline Afrika & 270 & 0.092 & 0.290 & 0 & 1 \\
\hline
\end{tabular}


Table A9. Re-estimation of Table 11 with justifiable-homosexuality as value

\begin{tabular}{c|cccccc}
\hline$\Delta_{m}$ & $(1)$ & $(2)$ & $(3)$ & $(4)$ & $(5)$ & (6) \\
\hline \multirow{3}{*}{$\left|r_{m}-r_{p}\right|$} & & & & & & \\
& 0.481 & & 0.341 & 0.217 & 0.315 & 0.202 \\
$\left|r_{m}-\hat{r}_{v}\right|$ & $(0.83)$ & & $(0.50)$ & $(0.29)$ & $(0.47)$ & $(0.27)$ \\
& & $3.062^{* * *}$ & $2.954^{* * *}$ & $3.078^{* * *}$ & $2.935^{* * *}$ & $3.055^{* * *}$ \\
Wave Dummies & & $(6.04)$ & $(5.82)$ & $(5.94)$ & $(6.44)$ & $(6.68)$ \\
Region Dummies & No & No & No & Yes & No & Yes \\
\hline \multirow{2}{*}{$N$} & 157 & No & No & No & Yes & Yes \\
\hline
\end{tabular}

$t$ statistics in parentheses; s.e. corrected for clustering at country level; cut-points not reported;

${ }^{+} p<0.10,{ }^{*} p<0.05,{ }^{* *} p<0.01,{ }^{* * *} p<0.001$

Table A10. Re-estimation of Table 11 with justifiable-divorce as value

\begin{tabular}{|c|c|c|c|c|c|c|}
\hline$\Delta_{m}$ & (1) & (2) & (3) & (4) & (5) & (6) \\
\hline \multirow{2}{*}{$\left|r_{m}-r_{p}\right|$} & 0.481 & & 0.496 & 0.380 & 0.468 & 0.375 \\
\hline & $(0.83)$ & & $(0.63)$ & $(0.45)$ & $(0.62)$ & $(0.46)$ \\
\hline \multirow[t]{2}{*}{$\left|r_{m}-\tilde{r}_{v}\right|$} & & $3.734^{* * *}$ & $3.650^{* * *}$ & $3.781^{* * *}$ & $3.632^{* * *}$ & $3.745^{* * *}$ \\
\hline & & (7.85) & (7.71) & (7.34) & (7.53) & (7.11) \\
\hline Wave Dummies & No & No & No & Yes & No & Yes \\
\hline Region Dummies & No & No & No & No & Yes & Yes \\
\hline$N$ & 157 & 162 & 156 & 156 & 156 & 156 \\
\hline
\end{tabular}

$t$ statistics in parentheses; s.e. corrected for clustering at country level; cut-points not reported;

${ }^{+} p<0.10,{ }^{*} p<0.05,{ }^{* *} p<0.01,{ }^{* * *} p<0.001$ 


\section{Appendix B1: Definition of democracy}

To identify democracies, we rely on the Freedom House Index and the Polity-IV index, two established measures of democracy. Since democracy is a complex concept, both indices provide multiple values and go beyond a binary definition of democracy. For discussion of different measures of democracy refer to Casper and Tufis (2003) and Munck and Verkuilen (2002). The construction of the Polity-IV measure is documented in Marshall et al. (2013). We follow the literature in deriving binary measures of democracy from both indices.

We use two basic indicators of democracy:

1. polity_$_{-} 7=1$ if polity $\geq 7$

2. free $=1$ if $\frac{p r+c l}{2}<3$

In the paper the combination of both definitions is used. Accordingly:

3. free_polity $=1$ if (polity_7=1 \& free $=1$ )

The definition of democracy based on the Polity-IV data (polity_7) follows Brückner and Ciccone (2011) and references therein. The definition of free follows the definition of the Freedom House of what constitutes a free country.

The polity-variable (polity) measures democracy on a scale from -10 to 10. The index freedom additively combines values of civic liberties ( $c l)$ and political rights $(p r)$. In contrast to the original $\mathrm{cl}$ and $\mathrm{pr}$ measures, which indicate higher levels of democratization with lower numerical values, the freedom variable is recoded so that higher values indicate higher levels of democratization. This variable takes values in the range of 2-14. The indicator democ_10 considers those countries as democracies, which have a democ-value of ten in the Polity-IV dataset. freedom_2 selects those countries as democracies which have the best marks on both, civic liberties and political rights. We also employ a binary democracy indicator (democracy) constructed by Boix et al. (Boix et al. 2012) and the Index of democratization (van_index) as constructed by Vanhanen (2003). Results remain robust to any definition of democracy. Table B2 depicts descriptive statistics for all democracy measures employed. The most restrictive variable (freedom_2) defines 32\% of countries as democratic. In contrast, according to the variable democracy about $77 \%$ of countries in the sample are democratic. As can be seen in Table B3, all measures of democracy are strongly correlated. Our results do not depend on the actual choice of democracy measure. 
Table B2. Summary statistics for measures of democracy

\begin{tabular}{c|ccccc}
\hline Variable & Obs & Mean & Std. Dev. & Min & Max \\
\hline & & & & & \\
free_polity & 270 & 0.604 & 0.490 & 0 & 1 \\
polity_7 & 271 & 0.712 & 0.454 & 0 & 1 \\
free & 290 & 0.603 & 0.490 & 0 & 1 \\
democracy & 191 & 0.775 & 0.419 & 0 & 1 \\
polity & 270 & 6.281 & 5.410 & -10 & 10 \\
democ_10 & 270 & 0.381 & 0.487 & 0 & 1 \\
freedom & 290 & 10.628 & 3.498 & 2 & 14 \\
freedom_2 & 290 & 0.303 & 0.461 & 0 & 1 \\
van_index & 245 & 24.214 & 11.860 & 0 & 46.1 \\
\hline
\end{tabular}

Table B3. Pearson correlation between measures of democracy

\begin{tabular}{c|ccccccc}
\hline & free_polity & polity_7 & free & democracy & polity & democ_10 & freedom \\
\hline free_polity & 1.0000 & & & & & & \\
polity_7 & $0.7867^{*}$ & 1.0000 & & & & & \\
free & $0.9769^{*}$ & $0.7549^{*}$ & 1.0000 & & & & \\
democracy & $0.6816^{*}$ & $0.8289^{*}$ & $0.7002^{*}$ & 1.0000 & & & \\
polity & $0.7105^{*}$ & $0.8320^{*}$ & $0.7131^{*}$ & $0.8823^{*}$ & 1.0000 & & \\
democ_10 & $0.6352^{*}$ & $0.4961^{*}$ & $0.6205^{*}$ & $0.4213^{*}$ & $0.5408^{*}$ & 1.0000 & \\
freedom & $0.8637^{*}$ & $0.8144^{*}$ & $0.8765^{*}$ & $0.7998^{*}$ & $0.8786^{*}$ & $0.6805^{*}$ & 1.0000 \\
freedom_2 & $0.5304^{*}$ & $0.4173^{*}$ & $0.5351^{*}$ & $0.3232^{*}$ & $0.4386^{*}$ & $0.7166^{*}$ & $0.6375^{*}$ \\
van_index & $0.7150^{*}$ & $0.6811^{*}$ & $0.7161^{*}$ & $0.7038^{*}$ & $0.7781^{*}$ & $0.6574^{*}$ & $0.8108^{*}$ \\
cl & $0.8432^{*}$ & $0.7578^{*}$ & $0.8527^{*}$ & $0.7105^{*}$ & $0.8231^{*}$ & $0.6943^{*}$ & $0.9775^{*}$ \\
pr & $0.8499^{*}$ & $0.8335^{*}$ & $0.8657^{*}$ & $0.8435^{*}$ & $0.8942^{*}$ & $0.6439^{*}$ & $0.9837^{*}$ \\
\hline
\end{tabular}

${ }^{*} \mathrm{p}<.05$

\section{Appendix B4: Measuring the policy bundle effect}

The policy bundle effect is measured by $\left|r_{m}-r_{v}\right| . r_{v}$ is the average response given to the survey question on inequality by those respondents who hold the median view on values in a given country and wave. In our preferred specification we recover the individuals endorsing median values from the post-materialist index. Alternatively, we use three questions regarding the justifiability of certain behavior, namely homosexuality, divorce and abortion.

*justifiability-values

The question: "Please tell me for each of the following statements whether you think it can always be justified, never be justified, or something in between, using this card. (Read out statements. Code one answer for each statement).

Homosexuality / Abortion / Divorce"

Response categories: "1 Never justifiable ... 10 Always justifiable" 
*the post-materialist index

The construction of the post-materialist index is described in Inglehart (1997). The index is constructed by aggregating post-materialist items which are either first or second choice from a battery of twelve items included in three questions. The resulting index runs from 0 (no post-materialist item is given high priority) to 5 (all five post-materialist items are given high priority). The response items which are considered post-materialist are indicated with an asterisk. The variable numbers refer to the aggregated WVS data (WVS 2009).

E001/E002 People sometimes talk about what the aims of this country should be for the next ten years. On this card are listed some of the goals which different people would give top priority. Would you please say which one of these you, yourself, consider the most important?

First choice / Second choice

1 A high level of economic growth

2 Strong defense forces

3 People have more say about how things are done $\left(^{*}\right)$

4 Trying to make our cities and countryside more beautiful

E003/E004 If you had to choose, which one of the things on this card would you say is most important? And which would be the next most important?

First choice / Second choice

1 Maintaining order in the nation

2 Give people more say(*)

3 Fighting rising prices

4 Protecting freedom of speech(*)

E005/E006 Here is another list. In your opinion, which one of these is most important? And what would be the next most important?

First choice / Second choice

1 A stable economy

2 Progress toward a less impersonal and more humane society(*)

3 Ideas count more than money(*)

4 The fight against crime 


\section{Appendix C: All descriptive tables and regression tables for the polity_7 sample}

Appendix $\mathrm{C}$ shows all tables of descriptive statistics and regression results based on the Polity-IV democracy measure (polity_7). The Table numbers in Appendix C correspond to those in the main text (e.g. Table C2 with polity_7 corresponds to Table 2 with free_polity).

Table C2. Absolute and relative frequency distribution of $\Delta_{i}$

\begin{tabular}{c|ccc}
\hline & \multicolumn{3}{|c}{ polity_7 } \\
\hline$\Delta_{i}$ & 1 & 0 & Total \\
\hline 0 & 57,979 & 24,985 & 82,964 \\
& 21.85 & 20.55 & 21.44 \\
1 & 47,724 & 19,079 & 66,803 \\
& 17.99 & 15.69 & 17.26 \\
2 & 56,274 & 23,347 & 79,621 \\
& 21.21 & 19.20 & 20.58 \\
3 & 32,302 & 17,027 & 49,329 \\
& 12.17 & 14.00 & 12.75 \\
4 & 71,068 & 37,169 & 108,237 \\
& 26.78 & 30.56 & 27.97 \\
Total & 265,347 & 121,607 & 386,954 \\
& 100.00 & 100.00 & 100.00 \\
\hline
\end{tabular}

Table C3. $\delta_{m}$ and $\Delta_{m}$ for democracies and non-democracies

\begin{tabular}{c|ccc|cccc}
\hline \multicolumn{7}{c}{ polity_7 } & \multicolumn{5}{c}{ polity_7 } \\
\hline$\delta_{m}$ & 1 & 0 & Total & $\Delta_{m}$ & 1 & 0 & Total \\
& & & & & & & \\
-3 & 2 & 0 & 2 & & & & \\
-2 & 14 & 3 & 17 & & & & \\
-1 & 15 & 4 & 19 & & & & \\
0 & 109 & 27 & 136 & 0 & 109 & 27 & 136 \\
1 & 35 & 24 & 59 & 1 & 50 & 28 & 78 \\
2 & 15 & 13 & 28 & 2 & 29 & 16 & 45 \\
3 & 3 & 6 & 9 & 3 & 5 & 6 & 11 \\
4 & 0 & 1 & 1 & 4 & 0 & 1 & 1 \\
& & & & & & & \\
Total & 193 & 78 & 271 & Total & 193 & 78 & 271 \\
\hline
\end{tabular}


Table C9. Ordered logit for the policy-bundle and the asymmetric-participation effect

\begin{tabular}{c|cccccc}
\hline$\Delta_{m}$ & $(1)$ & $(2)$ & $(3)$ & $(4)$ & $(5)$ & (6) \\
\hline \multirow{3}{*}{$\left|r_{m}-r_{p}\right|$} & & & & & & \\
& 0.315 & & $1.313^{+}$ & 1.228 & 1.143 & 1.051 \\
$\left|r_{m}-r_{v}\right|$ & $(0.68)$ & & $(1.72)$ & $(1.43)$ & $(1.46)$ & $(1.19)$ \\
& & $6.168^{* * *}$ & $6.139^{* * *}$ & $6.197^{* * *}$ & $6.273^{* * *}$ & $6.324^{* * *}$ \\
\multirow{2}{*}{ Wave Dummies } & & $(8.23)$ & $(7.81)$ & $(7.71)$ & $(7.77)$ & $(7.53)$ \\
Region Dummies & No & No & No & Yes & No & Yes \\
\hline \multirow{2}{*}{$N$} & 186 & No & No & No & Yes & Yes \\
\hline
\end{tabular}

$t$ statistics in parentheses; s.e. corrected for clustering at country level; cut-points not reported;

${ }^{+} p<0.10,{ }^{*} p<0.05,{ }^{* *} p<0.01,{ }^{* * *} p<0.001$

Table C10. Ordered logits with an alternative proxy for the asymmetric-participation effect

\begin{tabular}{|c|c|c|c|c|c|c|}
\hline$\Delta_{m}$ & (1) & (2) & (3) & (4) & (5) & (6) \\
\hline \multirow{2}{*}{$\left|r_{m}-r_{p}^{\prime}\right|$} & -0.158 & & 1.009 & 0.865 & 0.880 & 0.703 \\
\hline & $(-0.31)$ & & (1.18) & $(0.98)$ & $(0.97)$ & $(0.74)$ \\
\hline \multirow[t]{2}{*}{$\left|r_{m}-r_{v}\right|$} & & $6.168^{* * *}$ & $6.303^{* * *}$ & $6.315^{* * *}$ & $6.503^{* * *}$ & $6.511^{* * *}$ \\
\hline & & $(8.23)$ & $(7.76)$ & (7.65) & $(7.55)$ & $(7.36)$ \\
\hline Wave Dummies & No & No & No & Yes & No & Yes \\
\hline Region Dummies & No & No & No & No & Yes & Yes \\
\hline$N$ & 189 & 111 & 110 & 110 & 110 & 110 \\
\hline
\end{tabular}

$t$ statistics in parentheses; s.e. corrected for clustering at country level; cut-points not reported;

$+p<0.10,{ }^{*} p<0.05,{ }^{* *} p<0.01,{ }^{* * *} p<0.001$

Table C11. Ordered logits with an alternative proxy for the policy-bundle effect (abortion)

\begin{tabular}{c|cccccc}
\hline$\Delta_{m}$ & $(1)$ & $(2)$ & $(3)$ & $(4)$ & (5) & (6) \\
\hline \multirow{3}{*}{$\left|r_{m}-r_{p}\right|$} & & & & & & \\
& 0.315 & & 0.326 & 0.195 & 0.291 & 0.186 \\
$\left|r_{m}-r_{v}^{\prime}\right|$ & $(0.68)$ & & $(0.48)$ & $(0.28)$ & $(0.44)$ & $(0.28)$ \\
& & $4.995^{* * *}$ & $4.945^{* * *}$ & $5.042^{* * *}$ & $5.030^{* * *}$ & $5.104^{* * *}$ \\
Wave Dummies & & $(10.03)$ & $(10.17)$ & $(9.48)$ & $(9.60)$ & $(9.18)$ \\
Region Dummies & No & No & No & Yes & No & Yes \\
\hline \multirow{2}{*}{$N$} & 186 & No & No & No & Yes & Yes \\
\hline
\end{tabular}

$t$ statistics in parentheses; s.e. corrected for clustering at country level; cut-points not reported;

${ }^{+} p<0.10,{ }^{*} p<0.05,{ }^{* *} p<0.01,{ }^{* * *} p<0.001$ 
Table C12. Ordered logits with an alternative proxy for the policy-bundle effect (homosexuality)

\begin{tabular}{|c|c|c|c|c|c|c|}
\hline$\Delta_{m}$ & (1) & (2) & (3) & (4) & (5) & (6) \\
\hline \multirow{2}{*}{$\left|r_{m}-r_{p}\right|$} & 0.315 & & 0.379 & 0.285 & 0.344 & 0.256 \\
\hline & $(0.68)$ & & $(0.64)$ & $(0.45)$ & $(0.60)$ & $(0.41)$ \\
\hline \multirow[t]{2}{*}{$\left|r_{m}-\widehat{r}_{v}\right|$} & & $3.451^{* * *}$ & $3.373^{* * *}$ & $3.435^{* * *}$ & $3.398^{* * *}$ & $3.451^{* * *}$ \\
\hline & & (7.49) & $(7.26)$ & (7.36) & $(7.71)$ & (7.98) \\
\hline Wave Dummies & No & No & No & Yes & No & Yes \\
\hline Region Dummies & No & No & No & No & Yes & Yes \\
\hline$N$ & 186 & 189 & 183 & 183 & 183 & 183 \\
\hline
\end{tabular}

$t$ statistics in parentheses; s.e. corrected for clustering at country level; cut-points not reported;

${ }^{+} p<0.10,{ }^{*} p<0.05,{ }^{* *} p<0.01,{ }^{* * *} p<0.001$

Table C13. Ordered logits with an alternative proxy for the policy-bundle effect (divorce)

\begin{tabular}{c|cccccc}
\hline$\Delta_{m}$ & $(1)$ & $(2)$ & $(3)$ & $(4)$ & $(5)$ & $(6)$ \\
\hline \multirow{3}{*}{$\left|r_{m}-r_{p}\right|$} & & & & & & \\
& 0.315 & & 0.471 & 0.327 & 0.393 & 0.271 \\
$\left|r_{m}-\tilde{r}_{v}\right|$ & $(0.68)$ & & $(0.73)$ & $(0.48)$ & $(0.65)$ & $(0.42)$ \\
& & $3.504^{* * *}$ & $3.444^{* * *}$ & $3.553^{* * *}$ & $3.457^{* * *}$ & $3.530^{* * *}$ \\
\multirow{2}{*}{ Wave Dummies } & & $(8.67)$ & $(8.68)$ & $(8.36)$ & $(8.52)$ & $(8.08)$ \\
Region Dummies & No & No & No & Yes & No & Yes \\
\hline \multirow{2}{*}{$N$} & 186 & 190 & 184 & 184 & 184 & 184 \\
\hline
\end{tabular}

$t$ statistics in parentheses; s.e. corrected for clustering at country level; cut-points not reported;

${ }^{+} p<0.10,{ }^{*} p<0.05,{ }^{* *} p<0.01,{ }^{* * *} p<0.001$ 


\section{Appendix D: All descriptive tables and regression tables for the free sample}

Appendix D shows all tables of descriptive statistics and regression results based on the Freedom House democracy measure (free). The Table numbers in Appendix D correspond to those in the main text (e.g. Table D2 with free corresponds to Table 2 with free_polity).

Table D2. Absolute and relative frequency distribution of $\Delta_{i}$

\begin{tabular}{c|ccc}
\hline & \multicolumn{3}{|c}{ free } \\
\hline$\Delta_{i}$ & 1 & 0 & Total \\
\hline 0 & 52,348 & 34,390 & 86,738 \\
& 22.33 & 20.20 & 21.44 \\
1 & 44,446 & 25,646 & 70,092 \\
& 18.96 & 15.07 & 17.32 \\
2 & 51,055 & 32,258 & 83,313 \\
& 21.78 & 18.95 & 20.59 \\
3 & 28,021 & 23,329 & 51,350 \\
& 11.95 & 13.70 & 12.69 \\
4 & 58,559 & 54,602 & 113,161 \\
& 24.98 & 32.08 & 27.96 \\
Total & 234,429 & 170,225 & 404,654 \\
& 100.00 & 100.00 & 100.00 \\
\hline
\end{tabular}

Table D3. $\delta_{m}$ and $\Delta_{m}$ for democracies and non-democracies

\begin{tabular}{c|ccc|cccc}
\hline \multicolumn{2}{c}{ free } & \multicolumn{6}{c}{ free } \\
\hline$\delta_{m}$ & 1 & 0 & Total & $\Delta_{m}$ & 1 & 0 & Total \\
& & & & & & & \\
-3 & 1 & 1 & 2 & & & & \\
-2 & 13 & 5 & 18 & & & & \\
-1 & 13 & 7 & 20 & & & & \\
0 & 101 & 47 & 148 & 0 & 101 & 47 & 148 \\
1 & 33 & 29 & 62 & 1 & 46 & 36 & 82 \\
2 & 11 & 17 & 28 & 2 & 24 & 22 & 46 \\
3 & 3 & 8 & 11 & 3 & 4 & 9 & 13 \\
4 & 0 & 1 & 1 & 4 & 0 & 1 & 1 \\
& & & & & & & \\
Total & 175 & 115 & 290 & Total & 175 & 115 & 290 \\
\hline
\end{tabular}


Table D9. Ordered logit for the policy-bundle and the asymmetric-participation effect

\begin{tabular}{c|cccccc}
\hline$\Delta_{m}$ & $(1)$ & $(2)$ & $(3)$ & $(4)$ & $(5)$ & $(6)$ \\
\hline \multirow{3}{*}{$\left|r_{m}-r_{p}\right|$} & & & & & & \\
& 0.518 & & 1.092 & 0.931 & 1.004 & 0.811 \\
$\left|r_{m}-r_{v}\right|$ & $(0.88)$ & & $(0.87)$ & $(0.67)$ & $(0.77)$ & $(0.56)$ \\
& & $5.232^{* * *}$ & $5.361^{* * *}$ & $5.430^{* * *}$ & $5.406^{* * *}$ & $5.508^{* * *}$ \\
Wave Dummies & & $(8.01)$ & $(7.66)$ & $(7.47)$ & $(7.54)$ & $(7.17)$ \\
Region Dummies & No & No & No & Yes & No & Yes \\
\hline$N$ & 166 & No & No & No & Yes & Yes \\
\hline
\end{tabular}

$t$ statistics in parentheses; s.e. corrected for clustering at country level; cut-points not reported;

${ }^{+} p<0.10,{ }^{*} p<0.05,{ }^{* *} p<0.01,{ }^{* * *} p<0.001$

Table D10. Ordered logits with an alternative proxy for the asymmetric-participation effect

\begin{tabular}{|c|c|c|c|c|c|c|}
\hline$\Delta_{m}$ & (1) & (2) & (3) & (4) & (5) & (6) \\
\hline \multirow{2}{*}{$\left|r_{m}-r_{p}^{\prime}\right|$} & -0.186 & & 0.765 & 0.558 & 0.741 & 0.421 \\
\hline & $(-0.30)$ & & $(0.66)$ & $(0.45)$ & $(0.62)$ & $(0.31)$ \\
\hline \multirow{2}{*}{$\left|r_{m}-r_{v}\right|$} & & $5.232^{* * *}$ & $5.285^{* * *}$ & $5.293^{* * *}$ & $5.421^{* * *}$ & $5.451^{* * *}$ \\
\hline & & $(8.01)$ & $(8.03)$ & $(7.62)$ & $(7.52)$ & (7.19) \\
\hline Wave Dummies & No & No & No & Yes & No & Yes \\
\hline Region Dummies & No & No & No & No & Yes & Yes \\
\hline$N$ & 172 & 101 & 101 & 101 & 101 & 101 \\
\hline
\end{tabular}

$t$ statistics in parentheses; s.e. corrected for clustering at country level; cut-points not reported;

${ }^{+} p<0.10,{ }^{*} p<0.05,{ }^{* *} p<0.01,{ }^{* * *} p<0.001$

Table D11. Ordered logits with an alternative proxy for the policy-bundle effect (abortion)

\begin{tabular}{c|cccccc}
\hline$\Delta_{m}$ & $(1)$ & $(2)$ & $(3)$ & $(4)$ & $(5)$ & (6) \\
\hline \multirow{3}{*}{$\left|r_{m}-r_{p}\right|$} & & & & & & \\
& 0.518 & & 0.310 & 0.194 & 0.282 & 0.197 \\
$\left|r_{m}-r_{v}^{\prime}\right|$ & $(0.88)$ & & $(0.36)$ & $(0.21)$ & $(0.32)$ & $(0.22)$ \\
& & $4.972^{* * *}$ & $4.862^{* * *}$ & $4.936^{* * *}$ & $4.945^{* * *}$ & $4.994^{* * *}$ \\
Wave Dummies & & $(9.71)$ & $(9.31)$ & $(8.75)$ & $(8.91)$ & $(8.57)$ \\
Region Dummies & No & No & No & Yes & No & Yes \\
\hline \multirow{2}{*}{$N$} & 166 & No & No & No & Yes & Yes \\
\hline
\end{tabular}

$t$ statistics in parentheses; s.e. corrected for clustering at country level; cut-points not reported;

${ }^{+} p<0.10,{ }^{*} p<0.05,{ }^{* *} p<0.01,{ }^{* * *} p<0.001$ 
Table D12. Ordered logits with an alternative proxy for the policy-bundle effect (homosexuality)

\begin{tabular}{|c|c|c|c|c|c|c|}
\hline$\Delta_{m}$ & (1) & (2) & (3) & (4) & (5) & (6) \\
\hline \multirow{2}{*}{$\left|r_{m}-r_{p}\right|$} & 0.518 & & 0.375 & 0.268 & 0.367 & 0.269 \\
\hline & $(0.88)$ & & $(0.55)$ & $(0.36)$ & $(0.55)$ & $(0.36)$ \\
\hline \multirow[t]{2}{*}{$\left|r_{m}-\widehat{r}_{v}\right|$} & & $3.118^{* * *}$ & $2.969^{* * *}$ & $3.126^{* * *}$ & $2.965^{* * *}$ & $3.125^{* * *}$ \\
\hline & & (6.57) & (6.12) & $(6.21)$ & $(6.72)$ & (6.89) \\
\hline Wave Dummies & No & No & No & Yes & No & Yes \\
\hline Region Dummies & No & No & No & No & Yes & Yes \\
\hline$N$ & 166 & 173 & 164 & 164 & 164 & 164 \\
\hline
\end{tabular}

$t$ statistics in parentheses; s.e. corrected for clustering at country level; cut-points not reported;

${ }^{+} p<0.10,{ }^{*} p<0.05,{ }^{* *} p<0.01,{ }^{* * *} p<0.001$

Table D13. Ordered logits with an alternative proxy for the policy-bundle effect (divorce)

\begin{tabular}{|c|c|c|c|c|c|c|}
\hline$\Delta_{m}$ & $(1)$ & (2) & (3) & (4) & (5) & (6) \\
\hline \multirow{2}{*}{$\left|r_{m}-r_{p}\right|$} & 0.518 & & 0.511 & 0.389 & 0.483 & 0.382 \\
\hline & $(0.88)$ & & $(0.65)$ & $(0.46)$ & $(0.64)$ & $(0.47)$ \\
\hline \multirow[t]{2}{*}{$\left|r_{m}-\tilde{r}_{v}\right|$} & & $3.793^{* * *}$ & $3.630^{* * *}$ & $3.816^{* * *}$ & $3.626^{* * *}$ & $3.804^{* * *}$ \\
\hline & & (8.29) & $(8.10)$ & $(7.68)$ & (7.96) & $(7.51)$ \\
\hline Wave Dummies & No & No & No & Yes & No & Yes \\
\hline Region Dummies & No & No & No & No & Yes & Yes \\
\hline$N$ & 166 & 174 & 165 & 165 & 165 & 165 \\
\hline
\end{tabular}

$t$ statistics in parentheses; s.e. corrected for clustering at country level; cut-points not reported;

${ }^{+} p<0.10,{ }^{*} p<0.05,{ }^{* *} p<0.01,{ }^{* * *} p<0.001$ 